University of Nebraska - Lincoln

DigitalCommons@University of Nebraska - Lincoln

U.S. Environmental Protection Agency Papers

U.S. Environmental Protection Agency

2009

\title{
The impact of temperature on the performance of anaerobic biological treatment of perchlorate in drinking water
}

\author{
Nicholas R. Dugan \\ United States Environmental Protection Agency, dugan.nicholas@epa.gov \\ Daniel J. Williams \\ United States Environmental Protection Agency \\ Maria Meyer \\ Greater Cincinnati Water Works \\ Ross R. Schneider \\ Pegasus Technical Services \\ Thomas F. Speth \\ United States Environmental Protection Agency \\ See next page for additional authors
}

Follow this and additional works at: https://digitalcommons.unl.edu/usepapapers

Dugan, Nicholas R.; Williams, Daniel J.; Meyer, Maria; Schneider, Ross R.; Speth, Thomas F.; and Metz, Deborah $\mathrm{H}_{\text {., }}$ "The impact of temperature on the performance of anaerobic biological treatment of perchlorate in drinking water" (2009). U.S. Environmental Protection Agency Papers. 99.

https://digitalcommons.unl.edu/usepapapers/99

This Article is brought to you for free and open access by the U.S. Environmental Protection Agency at DigitalCommons@University of Nebraska - Lincoln. It has been accepted for inclusion in U.S. Environmental Protection Agency Papers by an authorized administrator of DigitalCommons@University of Nebraska - Lincoln. 
Authors

Nicholas R. Dugan, Daniel J. Williams, Maria Meyer, Ross R. Schneider, Thomas F. Speth, and Deborah H. Metz 


\title{
The impact of temperature on the performance of anaerobic biological treatment of perchlorate in drinking water
}

\author{
Nicholas R. Dugan ${ }^{a, *}$, Daniel J. Williams ${ }^{a}$, Maria Meyer ${ }^{b, 1}$, Ross R. Schneider ${ }^{c}$, \\ Thomas F. Speth ${ }^{a}$, Deborah H. Metz ${ }^{b}$ \\ ${ }^{a}$ United States Environmental Protection Agency, 26 West Martin Luther King Drive, Cincinnati, OH 45268, USA \\ ${ }^{\mathrm{b}}$ Greater Cincinnati Water Works, 5651 Kellogg Avenue, Cincinnati, OH 45228, USA \\ ${ }^{\mathrm{c}}$ Pegasus Technical Services, 46 East Hollister Street, Cincinnati, OH 45219, USA
}

\section{A R T I C L E I N F O}

Article history:

Received 14 November 2008

Received in revised form

29 January 2009

Accepted 30 January 2009

Published online 10 February 2009

Keywords:

Perchlorate

Biological treatment

Temperature effects

\begin{abstract}
A B S T R A C T
A 20-month pilot-scale study was conducted to examine the impact of temperature on the performance of an anaerobic biological contactor used to treat perchlorate-contaminated water. The contactor was successfully acclimated with indigenous microorganisms. Influent temperatures varied from 1.4 to $30^{\circ} \mathrm{C}$. The objectives of the study were to investigate the effects of temperature on perchlorate removal, nitrate removal, nitrite formation, dissolved oxygen consumption, sulfide production, and nutrient acetate consumption. The results confirmed that consistent biological perchlorate removal to $2 \mu \mathrm{g} / \mathrm{L}$ is feasible at temperatures above $10^{\circ} \mathrm{C}$. Effluent concentrations of perchlorate, nitrate, and dissolved oxygen varied inversely with temperature, while sulfide varied positively with temperature. Under the conditions that prevailed during this study, $10^{\circ} \mathrm{C}$ was a threshold temperature below which microbial activity, including perchlorate reduction, decreased dramatically.
\end{abstract}

Published by Elsevier Ltd.

\section{Introduction}

The perchlorate ion $\left(\mathrm{ClO}_{4}^{-}\right)$is an oxidant that has the potential to interfere with iodide $\left(\mathrm{I}^{-}\right)$uptake by the thyroid gland. The decreased iodide uptake can lead to decreased production of thyroid hormones which, in turn, could cause developmental problems in vulnerable sub-populations. Industrial production of perchlorate salts in the United States and Europe began in the early part of the 20th century (Schumacher, 1960). Perchlorate compounds are used in products and applications ranging from military ordnance, to matches, to electro polishing (Schumacher, 1960; Trumpolt et al., 2005). In addition to anthropogenic sources, researchers (Dasgupta et al., 2005) have proposed a mechanism for perchlorate formation by atmospheric processes. Perchlorate deposition from these processes is hypothesized as a source of dissolved perchlorate in regions with no apparent anthropogenic sources (Rajagopalan et al., 2006; Rao et al., 2007).

Perchlorate is highly soluble and mobile in aqueous solution and has been detected in numerous drinking water supplies. In a large survey in the United States (U.S. Environmental Protection Agency, 1999; U.S. Environmental Protection Agency, 2006; U.S. Environmental Protection Agency, 2007), perchlorate was detected at concentrations ranging from 4 to $200 \mu \mathrm{g} / \mathrm{L}$, with a mean of $10 \mu \mathrm{g} / \mathrm{L}$, in the influents of 69 ground water treatment systems. The same survey detected perchlorate in the influents of 52 surface water treatment systems, at concentrations ranging from 4 to $420 \mu \mathrm{g} / \mathrm{L}$, with

\footnotetext{
* Corresponding author. Tel.: +1 513569 7239; fax: +1 5135697172.

E-mail address: dugan.nicholas@epa.gov (N.R. Dugan).

${ }^{1}$ Was an employee of Pegasus Technical Services at the time the research was being performed. 0043-1354/\$ - see front matter Published by Elsevier Ltd.
} doi:10.1016/j.watres.2009.01.032 


\begin{tabular}{|ll|}
\hline Nomenclature \\
$\mu \mathrm{g} / \mathrm{L}$ & micrograms per liter \\
${ }^{\circ} \mathrm{C}$ & degrees Celsius \\
$\mathrm{L} / \mathrm{min}$ & liters per minute \\
$\mathrm{Cm}$ & centimeters \\
$\mathrm{mm}$ & millimeter \\
$\mathrm{mg} / \mathrm{L}$ & milligram per liter \\
$\mathrm{ppm}$ & parts per million \\
$\mathrm{MDL}$ & method detection limit \\
$\mathrm{D}_{10}$ & grain size for which 10 percent of the grains in \\
& a sample (by weight) are smaller \\
$\mathrm{D}_{60}$ & grain size for which 60 percent of the grains in \\
& a sample (by weight) are smaller \\
$\mathrm{T}$ & temperature \\
$\mathrm{HDPE}$ & high density polyethylene \\
$\mathrm{V}$ & volts \\
$\mathrm{E}_{\mathrm{O}}$ & reduction potential \\
$\sigma_{\mathrm{n}-1}$ & standard deviation \\
\hline
\end{tabular}

a mean of $10 \mu \mathrm{g} / \mathrm{L}$. The population data provided with the survey indicates a potentially high number of exposed individuals. Of the 69 ground water treatment systems, 51 systems served 10 thousand to 100 thousand people, and 13 systems served populations of more than 100 thousand. Of the 52 surface water treatment systems, 22 systems served 10 thousand to 100 thousand people, and 27 systems served populations of more than 100 thousand.

Perchlorate contamination also occurs outside the United States. A sampling campaign in Japan's Tome river watershed (Kosaka et al., 2007) detected perchlorate at concentrations ranging from 0.08 to $2300 \mu \mathrm{g} / \mathrm{L}$ in the upper watershed and $0.73-25 \mu \mathrm{g} / \mathrm{L}$ in the middle and lower portions of the watershed. A sampling effort in Korea (Quinones et al., 2007) detected perchlorate at concentrations ranging from 0.15 to $60 \mu \mathrm{g} / \mathrm{L}$ in the Nakdong river watershed and $0.08-2.3 \mu \mathrm{g} / \mathrm{L}$ in the Yeongsan river. The Tome, Nakdong, and Yeongsan rivers all serve as water sources for major population centers.

Evolving knowledge of the occurrence and health effects of perchlorate has spurred research into treatment technologies that include modified activated carbon, ion exchange, electro dialysis, reverse osmosis, and anaerobic biological treatment. Of these, biological treatment has the advantages of not requiring media regeneration or brine treatment. The biological process utilizes facultative anaerobic bacteria which, under the proper conditions, use perchlorate as an electron acceptor during metabolism (Xu et al., 2003; Coates and Achenbach, 2004). Through this metabolic pathway, perchlorate is reduced to chlorate $\left(\mathrm{ClO}_{3}^{-}\right)$, then chlorite $\left(\mathrm{ClO}_{2}^{-}\right)$, and finally chloride $\left(\mathrm{Cl}^{-}\right)$. Several pilot-scale studies (Min et al., 2004; Brown et al., 2005; Fuller et al., 2007) have demonstrated the ability of a biological process to treat influent waters contaminated with $40-100 \mu \mathrm{g} / \mathrm{L}$ perchlorate and produce effluents with concentrations of $4 \mu \mathrm{g} / \mathrm{L}$ perchlorate or less. These studies ran from 92 to 166 days and investigated the treatment of perchlorate contaminated well waters. Min et al. (2004) reported an average temperature of $20^{\circ} \mathrm{C} \pm 0.7^{\circ} \mathrm{C}$. Brown et al. (2005) reported temperatures of $16^{\circ} \mathrm{C}$ and $19^{\circ} \mathrm{C}$ from wells sampled prior to the initiation of their study. Fuller et al. (2007) maintained temperatures of $12-15^{\circ} \mathrm{C}$. Seasonal temperature fluctuations in ground water, if present at all, are mild compared to those observed in many surface waters. Given the number of surface water perchlorate detections, an investigation of temperature impacts on biological treatment would be a useful addition to the existing body of knowledge on perchlorate treatment. To address this gap, a 20-month pilot-scale trial was undertaken using surface water with a temperature that varied from 1.4 to $30^{\circ} \mathrm{C}$. The objectives of the study were to investigate the impacts of temperature on perchlorate removal, nitrate $\left(\mathrm{NO}_{3}^{-}\right)$removal, nitrite $\left(\mathrm{NO}_{2}^{-}\right)$ formation, dissolved oxygen $\left(\mathrm{O}_{2}\right)$ consumption, sulfide $\left(\mathrm{S}^{2-}\right)$ production, and nutrient acetate $\left(\mathrm{CH}_{3} \mathrm{COO}^{-}\right)$consumption.

\section{Materials and methods}

\subsection{Pilot-scale contactor}

For the pilot-scale treatment system shown in Fig. 1, granular activated carbon contactor influent from the Greater Cincinnati Water Works' Ohio River treatment plant (Greater Cincinnati Water Works, 2007) was used as raw water for the system. The raw dissolved organic carbon, $\mathrm{pH}$, and turbidity over the course of the study averaged $1.9 \mathrm{mg} / \mathrm{L}\left(\sigma_{\mathrm{n}-1}=0.50 \mathrm{mg} /\right.$ L), $7.6\left(\sigma_{\mathrm{n}-1}=0.26\right)$, and $0.11 \mathrm{NTU}\left(\sigma_{\mathrm{n}-1}=0.023 \mathrm{NTU}\right)$, respectively. ${ }^{2}$ This water did not contain a disinfectant residual and had not been treated with disinfectants of any kind prior to use in the pilot-scale system. The contactor was acclimated with microorganisms indigenous to this water supply. No additional organisms were seeded into the system during the study.

The raw water flowed into a constant head tank and from there was pumped to the top of the anaerobic contactor with a constant speed pump (March Pumps, Glenview, Illinois, USA). A valve was used to adjust the influent flow rate to $3 \mathrm{~L} /$ min. The contactor influent line was constructed of $1.3-\mathrm{cm}$ inside diameter schedule 80 polyvinyl chloride (PVC) pipe and $1.3-\mathrm{cm}$ outside diameter teflon or stainless steel tubing. The influent line was equipped with four injection ports to facilitate the feeding of chemicals into the flow stream. All chemicals were of reagent grade and were fed with peristaltic pumps (Cole Parmer, Vernon Hills, Illinois, USA).

Sodium perchlorate $\left(\mathrm{NaClO}_{4} \cdot \mathrm{H}_{2} \mathrm{O}\right)$ and monobasic sodium phosphate $\left(\mathrm{NaH}_{2} \mathrm{PO}_{4} \cdot \mathrm{H}_{2} \mathrm{O}\right)$ (Fisher Scientific, Pittsburgh, Pennsylvania, USA) were fed to achieve final target concentrations of $50 \mu \mathrm{g} / \mathrm{L}$ as $\mathrm{ClO}_{4}^{-}$and $100 \mu \mathrm{g} / \mathrm{L}$ as phosphate $\left(\mathrm{PO}_{4}^{3-}\right)$ for the duration of the study. Phosphate served as a microbial nutrient. Acetic acid $\left(\mathrm{CH}_{3} \mathrm{COOH}\right)$ (GFS Chemicals, Powell, Ohio, USA) was fed to supply acetate $\left(\mathrm{CH}_{3} \mathrm{COO}^{-}\right)$, which served as a carbon source and electron donor. During Phase I, a high initial acetate concentration $(60-80 \mathrm{mg} / \mathrm{L})$ was fed to ensure that acetate was not rate limiting. The influent acetate concentration was subsequently varied in response to observed utilization in the contactor, stabilizing at $18-27 \mathrm{mg} / \mathrm{L}$ during Phase II. The acetate injection port was initially located upstream of the static mixer; however, acetate addition promoted luxuriant biomass accumulation that led to

\footnotetext{
${ }^{2} \sigma_{\mathrm{n}-1}=$ standard deviation.
} 


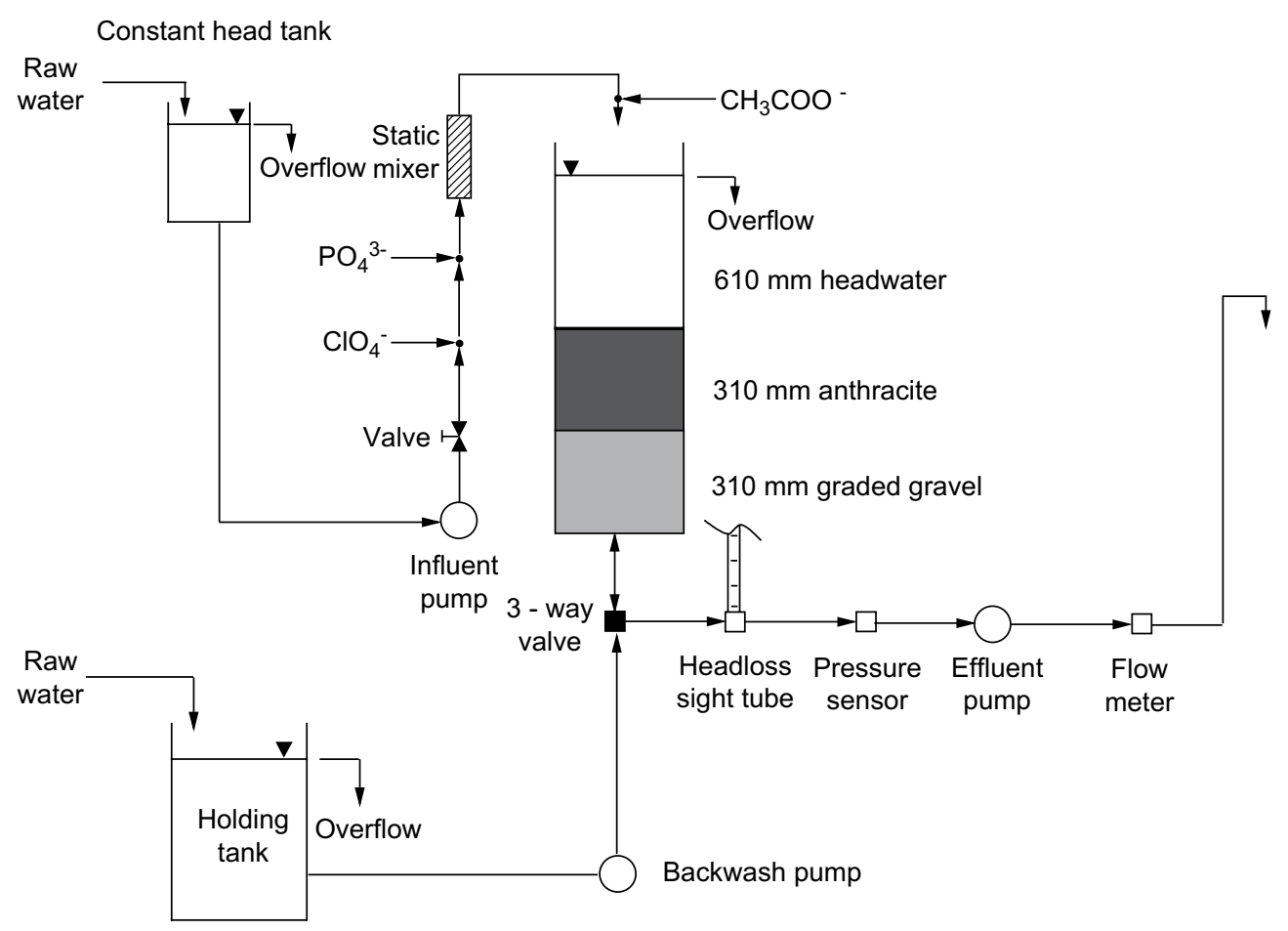

Fig. 1 - Pilot-scale treatment system.

frequent clogging of the influent plumbing. To facilitate easy cleaning, the acetate injection port was placed immediately upstream of the point where the influent discharged into the contactor head water. No flow problems were observed after the relocation.

The biological contactor was operated in a downflow mode. The contactor was a high density polyethylene (HDPE) tank (Snyder Industries, Lincoln, Nebraska, USA), with a height and inside diameter of $145 \mathrm{~cm}$ and $76 \mathrm{~cm}$, respectively. The contactor was supported $46 \mathrm{~cm}$ off the floor to make room for pumps and plumbing. The inside bottom of the contactor was fitted with a manifold to collect effluent and evenly distribute backwash water. The manifold was fabricated of 3.8-cm inside diameter schedule 80 PVC pipe, sealed at the ends, and drilled with $0.6-\mathrm{cm}$ holes at regular intervals. The manifold was covered with a bed of graded gravel (Northern Filter Media, Muscatine, Iowa, USA) to a depth of $31 \mathrm{~cm}$. A 31-cm bed of anthracite media (Northern Filter Media, Muscatine, Iowa, USA) was placed on top of the gravel. The anthracite had an effective diameter $\left(D_{10}\right)$ of $1.0 \mathrm{~mm}$ and a uniformity coefficient $\left(D_{60} / D_{10}\right)$ of 1.3 . The water depth over the top of the filter bed was $61 \mathrm{~cm}$. Four overflow fittings, each 5.1-cm inside diameter, were installed around the perimeter of the contactor to collect overflow and carry backwash water to waste. A variable speed gear pump (Micropump, Vancouver, Washington, USA) was used to maintain a hydraulic loading rate of $0.26 \mathrm{~m} / \mathrm{h}$. The contactor effluent line was equipped with a sight tube, pressure sensor (Dwyer Instruments, Michigan City, Indiana, USA), and flow meter (Georg Fisher Signet, El Monte, California, USA) to monitor head loss and flow rate.

A $1.1 \mathrm{~kW}$ centrifugal pump (EBARA, Rock Hill, South Carolina, USA) was used to pump backwash water from a 1900-L holding tank (Snyder Industries, Lincoln, Nebraska, USA). The holding tank was filled with the same raw water used to supply the contactor. All backwash plumbing was $3.8-\mathrm{cm}$ inside diameter schedule 80 PVC pipe. Backwashing was performed for $10 \mathrm{~min}$ at a time at a surface loading rate of $37 \mathrm{~m} / \mathrm{h}$. The contactor was backwashed weekly or when head loss exceeded $25 \mathrm{~cm}$.

\subsection{Sampling and analysis}

Temperature was measured manually, either with a thermocouple (Cole-Parmer, Vernon Hills, Illinois, USA) or alcohol thermometer. The $\mathrm{pH}$ was measured with a combination electrode and meter (Thermo Electron, Pittsburgh, Pennsylvania, USA), calibrated daily at $\mathrm{pH} 4,7$, and 10. Perchlorate was measured according to EPA Method 314.0 (U.S. Environmental Protection Agency, 2000) using a Dionex DX2500 ion chromatograph (Sunnyvale, California, USA) equipped with an AS11 column, guard column, and self-regenerating suppressor. Acetate was measured using a Dionex DX500 ion chromatograph equipped with an AS16 column, guard column, and self-regenerating suppressor. The eluent was $10 \mathrm{mM}$ sodium hydroxide $(\mathrm{NaOH})$. Dissolved organic carbon was measured according to Standard Method 5310-C (Standard methods, 2005) using a Dohrmann Phoenix 8000 analyzer (Mason, Ohio, USA). Perchlorate, acetate, and dissolved organic carbon samples were filtered through $0.2 \mu \mathrm{m}$ membranes into $40-\mathrm{mL}$ glass vials at the time of collection. Nitrate and nitrite samples analyzed in the laboratory were measured according to EPA Method 353.2 (U.S. Environmental Protection Agency, 1993). Ammonia $\left(\mathrm{NH}_{3}\right)$ was analyzed in the laboratory according to EPA Method 350.1 (U.S. Environmental Protection Agency, 1993). Laboratory analyses for nitrate, 
nitrite, and ammonia were carried out on a Westco Smartchem 200 discrete analyzer (Brookfield, CT, USA). Field measurements for nitrite and total sulfides were performed according to Hach Methods 8507 and 8131 (Hach Company, 2008), respectively, using a DR2000 spectrophotometer (Hach Company, Loveland, Colorado, USA). The sulfide method did not differentiate between the various sulfide compounds that may have been present. High $(>0.8 \mathrm{mg} / \mathrm{L})$ and low $(\leq 0.8 \mathrm{mg} / \mathrm{L})$ range dissolved oxygen concentrations were measured according to Hach Methods 8166 and 8316 (Hach Company, 2008), respectively, using a DR2000 spectrophotometer. Iron (Fe) and sulfate $\left(\mathrm{SO}_{4}^{2-}\right)$ were measured according to EPA Method 200.7 (U.S. Environmental Protection Agency, 1994) using a Thermo Electron iCAP 6000 inductively coupled plasma emission spectrometer. Laboratory samples for nitrate, nitrite, ammonia, iron, and sulfate were collected in 60-mL HDPE bottles.

\section{Results}

\subsection{Phase I}

Phase I was an 85-day acclimation period, defined as the time necessary for the contactor effluent perchlorate concentration (Fig. 2) to stabilize at or below the method detection limit (MDL) of $2 \mu \mathrm{g} / \mathrm{L}$. The water temperatures on the first and last days of Phase I were $5.7^{\circ} \mathrm{C}$ and $20^{\circ} \mathrm{C}$, respectively.

Indications of microbial activity were observed early on while the water was still cold. The differences between influent and effluent dissolved oxygen (Fig. 3) during the first and second weeks averaged $1.5 \mathrm{mg} / \mathrm{L}\left(\sigma_{\mathrm{n}-1}=0.44 \mathrm{mg} / \mathrm{L}\right)$ and $3.8 \mathrm{mg} / \mathrm{L} \quad\left(\sigma_{\mathrm{n}-1}=1.2 \mathrm{mg} / \mathrm{L}\right)$, respectively. Effluent dissolved oxygen concentrations dropped to less than $1 \mathrm{mg} / \mathrm{L}$ $(\mathrm{MDL}=0.008 \mathrm{mg} / \mathrm{L}$ ) after 30 days and less than $0.5 \mathrm{mg} / \mathrm{L}$ after 37 days. In contrast, the average influent dissolved oxygen over the first 37 days was $11 \mathrm{mg} / \mathrm{L}\left(\sigma_{\mathrm{n}-1}=1.2 \mathrm{mg} / \mathrm{L}\right)$. The water temperature by day 37 was $8.1^{\circ} \mathrm{C}$. Effluent nitrate concentrations (Fig. 4) began decreasing by day 16 and had stabilized at or below the MDL of $0.020 \mathrm{mg} / \mathrm{L}$ by day 28 . The influent nitrate concentration over this same time period averaged $0.97 \mathrm{mg} / \mathrm{L}$ $\left(\sigma_{\mathrm{n}-1}=0.25 \mathrm{mg} / \mathrm{L}\right)$. Effluent nitrite concentrations (Fig. 5) were at or below the MDL of $0.01 \mathrm{mg} / \mathrm{L}$ until day 16 , when they began increasing to a peak of $0.12 \mathrm{mg} / \mathrm{L}$ on day 28 . Nitrite levels then dropped off rapidly, returning to the MDL by day 36. Influent nitrite concentrations were always below the MDL. The acetate (Fig. 6) utilization rate remained constant, averaging $34 \%\left(\sigma_{n-1}=5.1 \%\right)$. The influent acetate concentration was progressively decreased during Phase I in order to bring the applied acetate into line with the amount utilized in the contactor.

Significant decreases in effluent perchlorate (Fig. 2) concentrations, compared to the influent, were observed by day 35. The timing of this decrease coincided with the establishment of stable effluent nitrate concentrations at or below the $0.020 \mathrm{mg} / \mathrm{L}$ MDL. Effluent perchlorate concentrations decreased steadily from then on, approaching the MDL of $2.0 \mu \mathrm{g} / \mathrm{L}$ by day 65 . The water temperature on day 65 was $16^{\circ} \mathrm{C}$. From then until the end of Phase I, however, effluent perchlorate fluctuated between 3.6 and $15 \mu \mathrm{g} / \mathrm{L}$ before stabilizing completely at the MDL by day 85 . By comparison, the influent perchlorate concentration during Phase I averaged $52 \mu \mathrm{g} / \mathrm{L}\left(\sigma_{\mathrm{n}-1}=7.4 \mu \mathrm{g} / \mathrm{L}\right)$.

The pilot system raw $\mathrm{pH}$, prior to acetic acid addition, averaged $8.0\left(\sigma_{\mathrm{n}-1}=0.19\right)$ during Phase I. The $\mathrm{pH}$ dropped by almost 2 units following acetic acid addition. The influent $\mathrm{pH}$ averaged $6.1\left(\sigma_{\mathrm{n}-1}=0.086\right)$ during the first week, rising to an average of $6.3\left(\sigma_{n-1}=0.094\right)$ during the last week of Phase I. The rise in influent $\mathrm{pH}$ was due to the progressive decrease in acetic acid dose that occurred during Phase I. Effluent $\mathrm{pH}$ increased from an average of $6.3\left(\sigma_{\mathrm{n}-1}=0.11\right)$ during the first week, to $6.8\left(\sigma_{\mathrm{n}-1}=0.044\right)$ over the same set of time intervals.

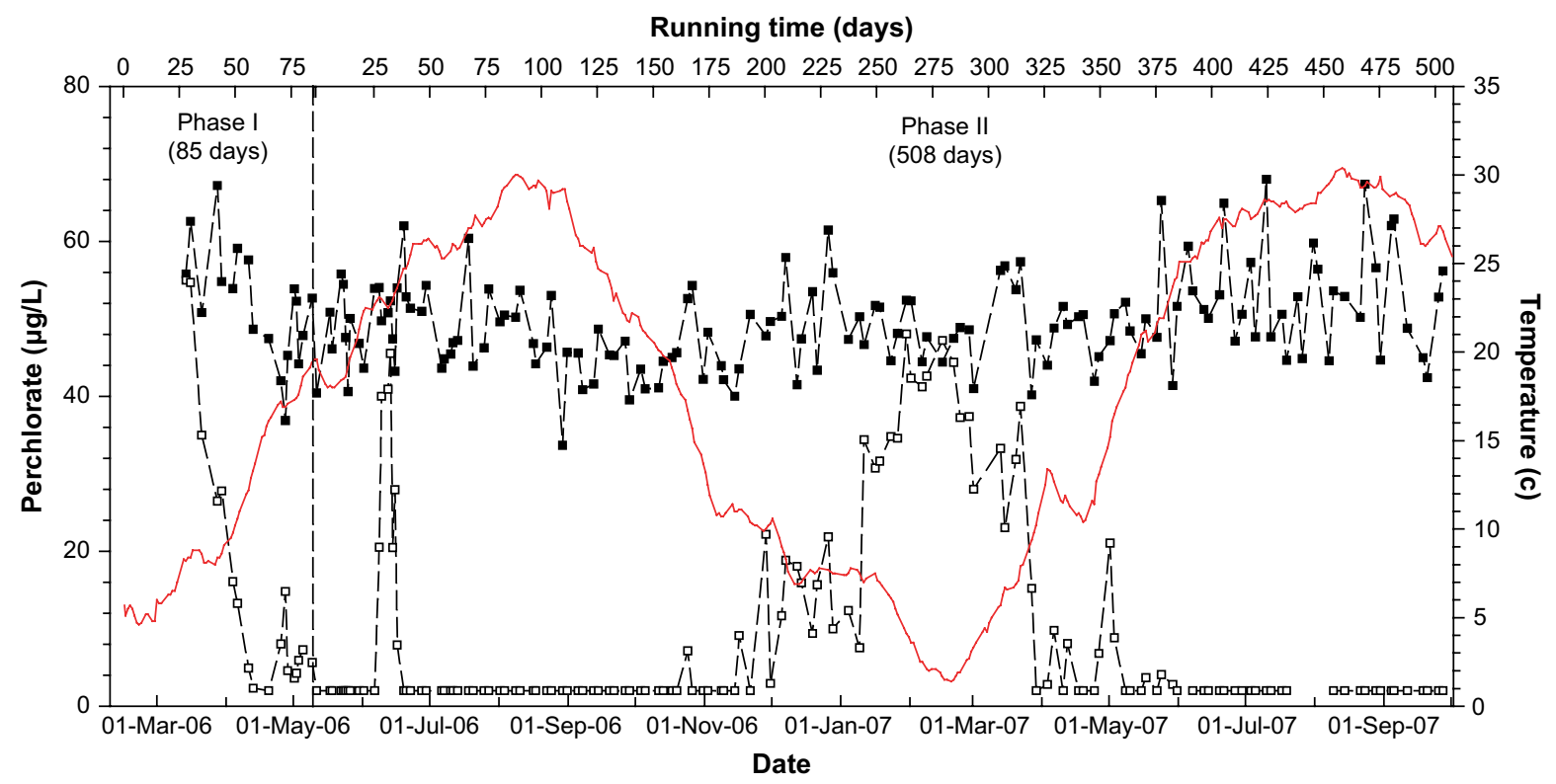

Fig. 2 - Perchlorate and temperature: $-\rightarrow-$ Contactor influent concentration (left axis), $-\rightarrow-$ Contactor effluent concentration (left axis), — Temperature (right axis), Perchlorate MDL $=0.002 \mathrm{mg} / \mathrm{L}$. 


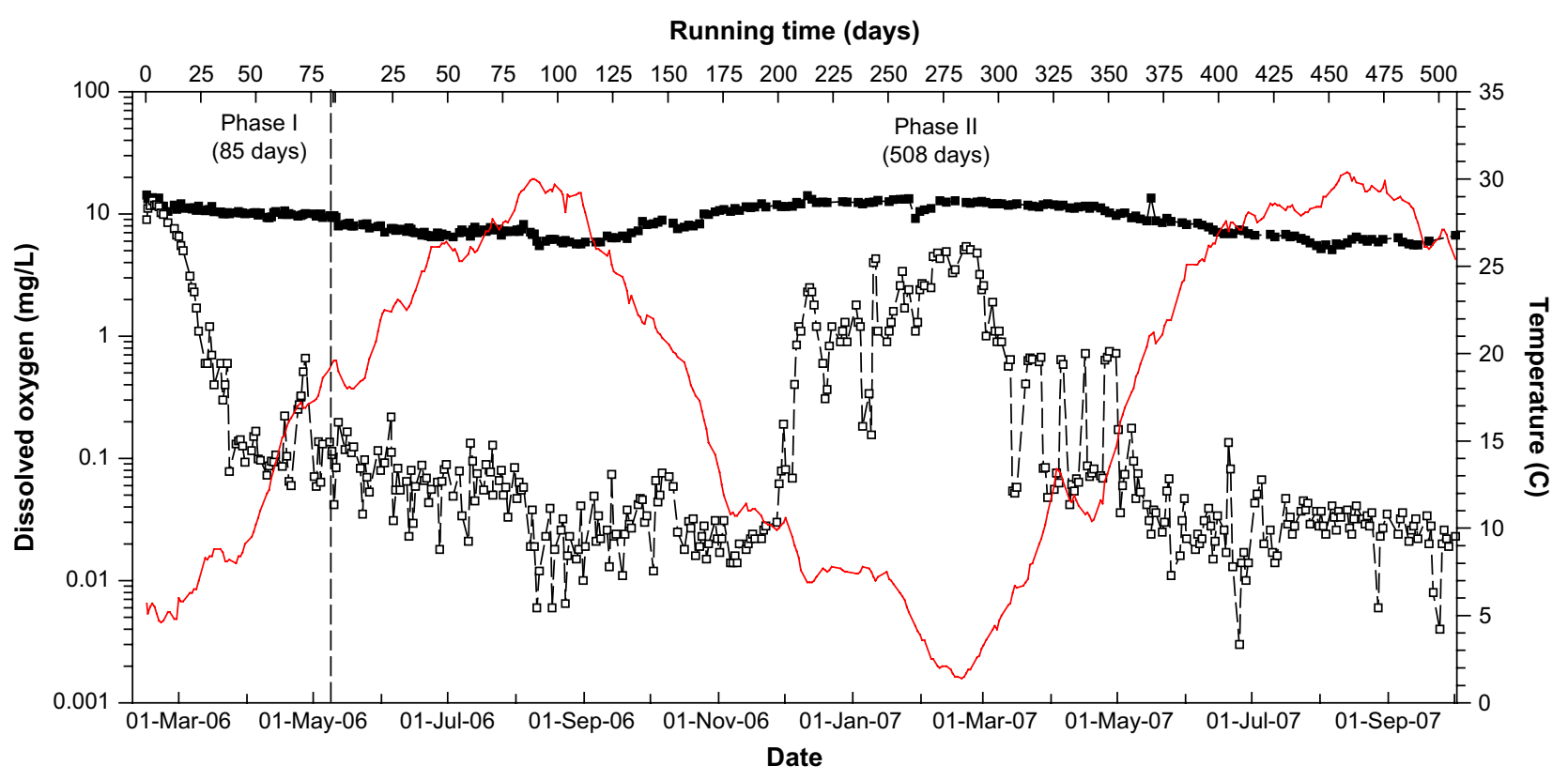

Fig. 3 - Dissolved oxygen and temperature: $-\rightarrow-$ Contactor influent concentration (left axis), --- - Contactor effluent concentration (left axis), —_ Temperature (right axis), Dissolved oxygen MDL $=0.008 \mathrm{mg} / \mathrm{L}$.

The $\mathrm{pH}$ increase across the contactor was attributed to microbial uptake of undissociated $\mathrm{CH}_{3} \mathrm{COOH}$.

Effluent iron concentrations (Fig. 7) began to increase significantly, versus the influent, by day 35. The beginning of this increase coincided with effluent dissolved oxygen levels dropping below $1 \mathrm{mg} / \mathrm{L}$. Effluent iron concentrations reached $0.21 \mathrm{mg} / \mathrm{L}$ by the end of Phase I. Influent iron concentrations over the same time interval averaged $<4.3 \mu \mathrm{g} / \mathrm{L}\left(\sigma_{\mathrm{n}-1}=2.4 \mu \mathrm{g} / \mathrm{L}\right){ }^{3}$

\subsection{Phase II}

Phase II was a 508-day quasi steady-state operational period that was defined as beginning when the effluent perchlorate stabilized below the $2.0 \mu \mathrm{g} / \mathrm{L}$ MDL. The goal during Phase II was to feed the minimum amount of acetate necessary to maintain full biological perchlorate reduction. The process of lowering influent acetate concentrations, begun during Phase I, was continued until effluent acetate levels dropped below the MDL of $1.0 \mu \mathrm{g} / \mathrm{L}$ between days 26 and 35 of Phase II. From this point on, influent acetate concentrations were raised or lowered as needed to provide sufficient electron donor while maintaining effluent concentrations between the MDL and $5 \mathrm{mg} / \mathrm{L}$. This dosing strategy was adopted to ensure that acetate was not a limiting factor in contactor operation. One consequence of this strategy, though, was the frequent presence of acetate in the anaerobic contactor effluent. These acetate concentrations would necessitate the installation of an aerobic biologically active filter to polish and stabilize the effluent prior to the distribution system.

\footnotetext{
${ }^{3}$ A " $<$ " preceding an average indicates that the value includes observations below the MDL, but incorporated in the calculation at the MDL.
}

Effluent perchlorate (Fig. 2) concentrations, which had remained below the $2.0 \mu \mathrm{g} / \mathrm{L}$ MDL for the first four weeks of Phase II, began to increase steadily on day 28. Effluent perchlorate peaked at $46 \mu \mathrm{g} / \mathrm{L}$ on day 33 , before falling back below the MDL by day 39. The average influent concentration during this excursion was $50 \mu \mathrm{g} / \mathrm{L}\left(\sigma_{\mathrm{n}-1}=3.9 \mu \mathrm{g} / \mathrm{L}\right)$. Possible reasons for the excursion are presented in the second paragraph of the following discussion section. With one exception, effluent perchlorate concentrations then stayed below the MDL from days 39 to 189 . By day 189 , the temperature had dropped to $11^{\circ} \mathrm{C}$. From this point onward, effluent perchlorate concentrations rose until, by day 264 , there was no significant difference between influent and effluent. The period of zero removal continued until day 285 and coincided with the lowest temperatures of the winter. The temperatures fell from $4.1^{\circ} \mathrm{C}$ on day 264 to $1.5^{\circ} \mathrm{C}$ on day 285 . Effluent perchlorate concentrations then began to drop steadily, reaching the MDL for the first time on day 322 , when the temperature had risen to $10^{\circ} \mathrm{C}$. From this point on, however, the contactor effluent did not stabilize below the MDL until day 385 , when the temperature reached $24^{\circ} \mathrm{C}$. The effluent perchlorate during this time interval ranged from the MDL to $21 \mu \mathrm{g} / \mathrm{L}$, with a mean of $<4.6 \mu \mathrm{g} / \mathrm{L}$. Effluent acetate (Fig. 6) concentrations between days 322 and 385 averaged $3.4 \mathrm{mg} / \mathrm{L}$ $\left(\sigma_{\mathrm{n}-1}=4.7 \mathrm{mg} / \mathrm{L}\right)$ with zero non-detects, indicating that sufficient electron donor had been made available. Effluent perchlorate concentrations then remained below the MDL from day 385 through the end of Phase II.

The time course of nitrate reduction during Phase II coincided almost exactly with the observed time course of perchlorate reduction. Effluent nitrate (Fig. 4) concentrations remained stable at or near the $20 \mu \mathrm{g} / \mathrm{L}$ MDL for the first 28 days and then spiked rapidly to a peak of $0.82 \mathrm{mg} / \mathrm{L}$ on day 33. The timing of the effluent nitrate peak coincided with the timing of a $46 \mu \mathrm{g} / \mathrm{L}$ effluent perchlorate peak and a $2.1 \mathrm{mg} / \mathrm{L}$ influent 
Running time (days)

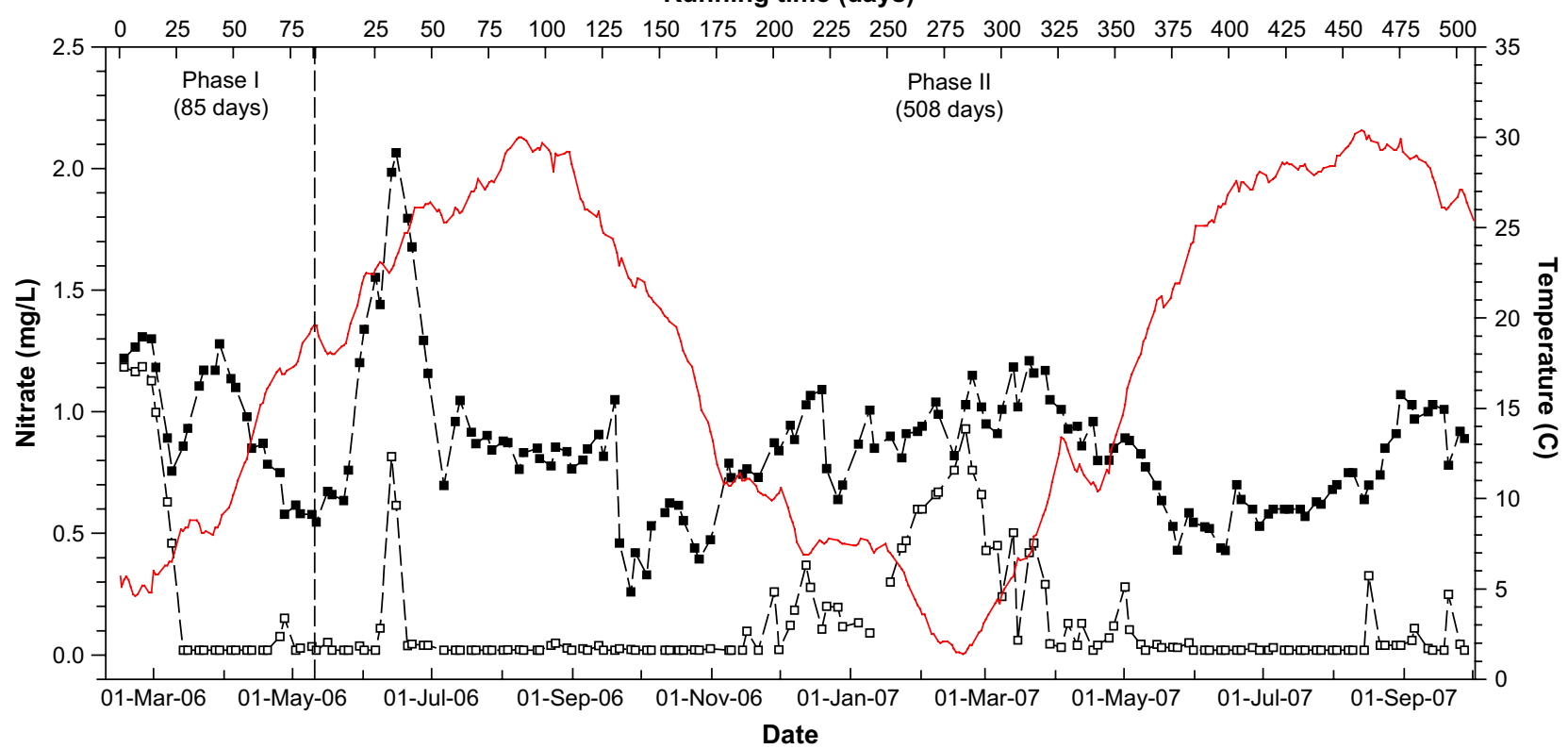

Fig. 4 - Nitrate and temperature: $-\rightarrow-$ Contactor influent concentration (left axis), --- Contactor effluent concentration (left axis), — Temperature (right axis), Nitrate MDL $=0.02 \mathrm{mg} / \mathrm{L}$.

nitrate peak. This peak influent nitrate concentration was more than four standard deviations greater than the mean influent nitrate of $0.90 \mathrm{mg} / \mathrm{L}\left(\sigma_{\mathrm{n}-1}=0.27 \mathrm{mg} / \mathrm{L}\right)$ observed for the entire study. Following this excursion, effluent nitrate concentrations from days 40 through 187 stabilized between the MDL and $50 \mu \mathrm{g} / \mathrm{L}$, averaging $<24 \mu \mathrm{g} / \mathrm{L}\left(\sigma_{\mathrm{n}-1}=8.2 \mu \mathrm{g} / \mathrm{L}\right)$. From day 187 , when the temperature was $11^{\circ} \mathrm{C}$, effluent nitrate levels increased to a peak of $0.93 \mathrm{mg} / \mathrm{L}$ on day 285 , when the temperature had dropped to $1.5^{\circ} \mathrm{C}$. Effluent nitrates then began to decrease steadily, dropping to below $50 \mu \mathrm{g} / \mathrm{L}$ for the first time on day 322, when the temperatures had climbed to $10^{\circ} \mathrm{C}$. However, effluent nitrate levels did not stabilize below $50 \mu \mathrm{g} / \mathrm{L}$ until day 383, when the temperature reached $24^{\circ} \mathrm{C}$. With the exception of isolated excursions on days 462 , 482 , and 497, effluent nitrates were then stable between the MDL and $50 \mu \mathrm{g} / \mathrm{L}$ for the remainder of Phase II.

With two exceptions, effluent nitrite (Fig. 5) concentrations during Phase II stayed at or below the $10 \mu \mathrm{g} / \mathrm{L}$ MDL. An effluent

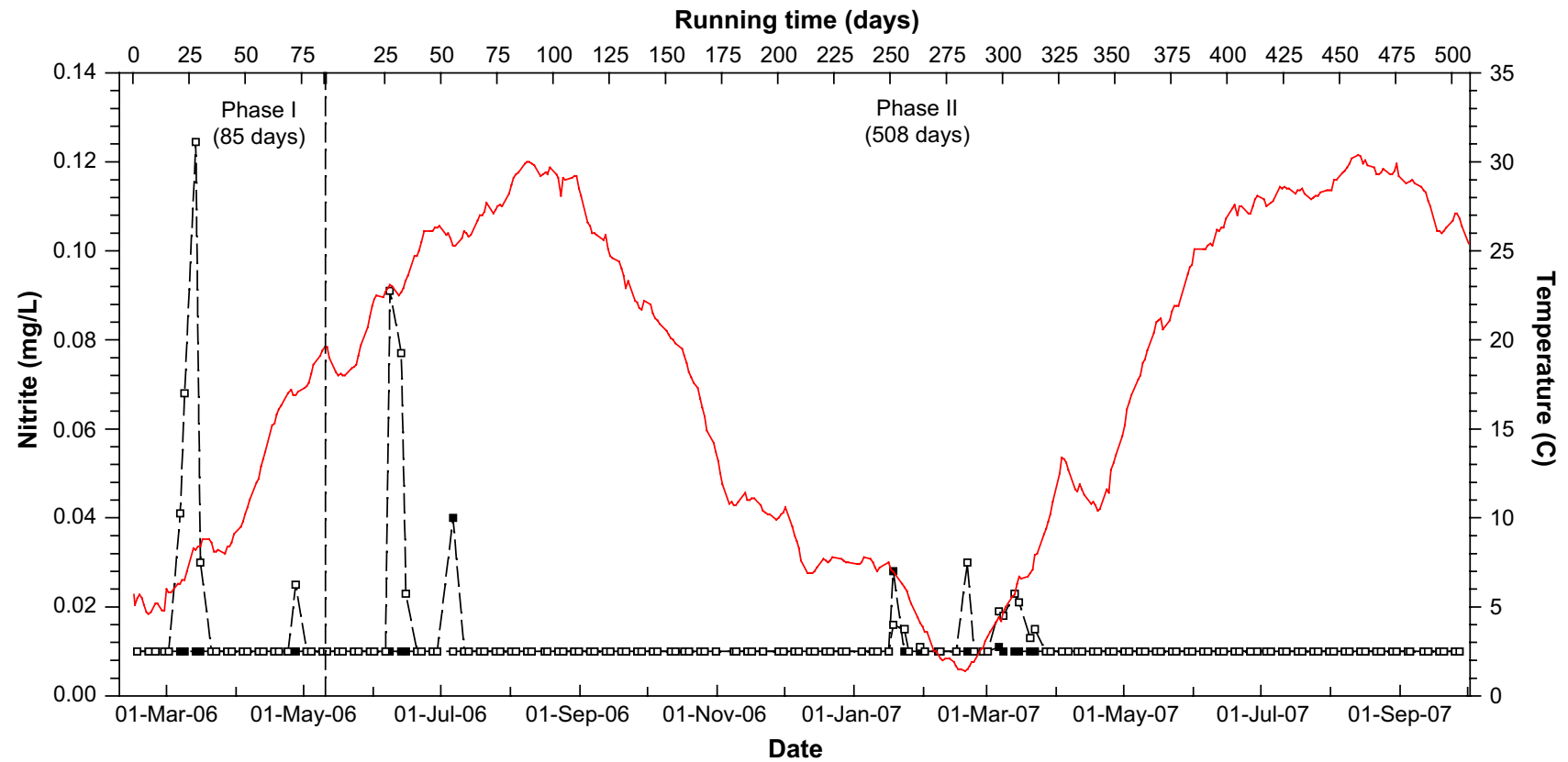

Fig. 5 - Nitrite and temperature: $-\rightarrow-$ Contactor influent concentration (left axis), ---- Contactor effluent concentration (left axis), _ Temperature (right axis), Nitrite $\mathrm{MDL}=0.01 \mathrm{mg} / \mathrm{L}$. 
Running time (days)

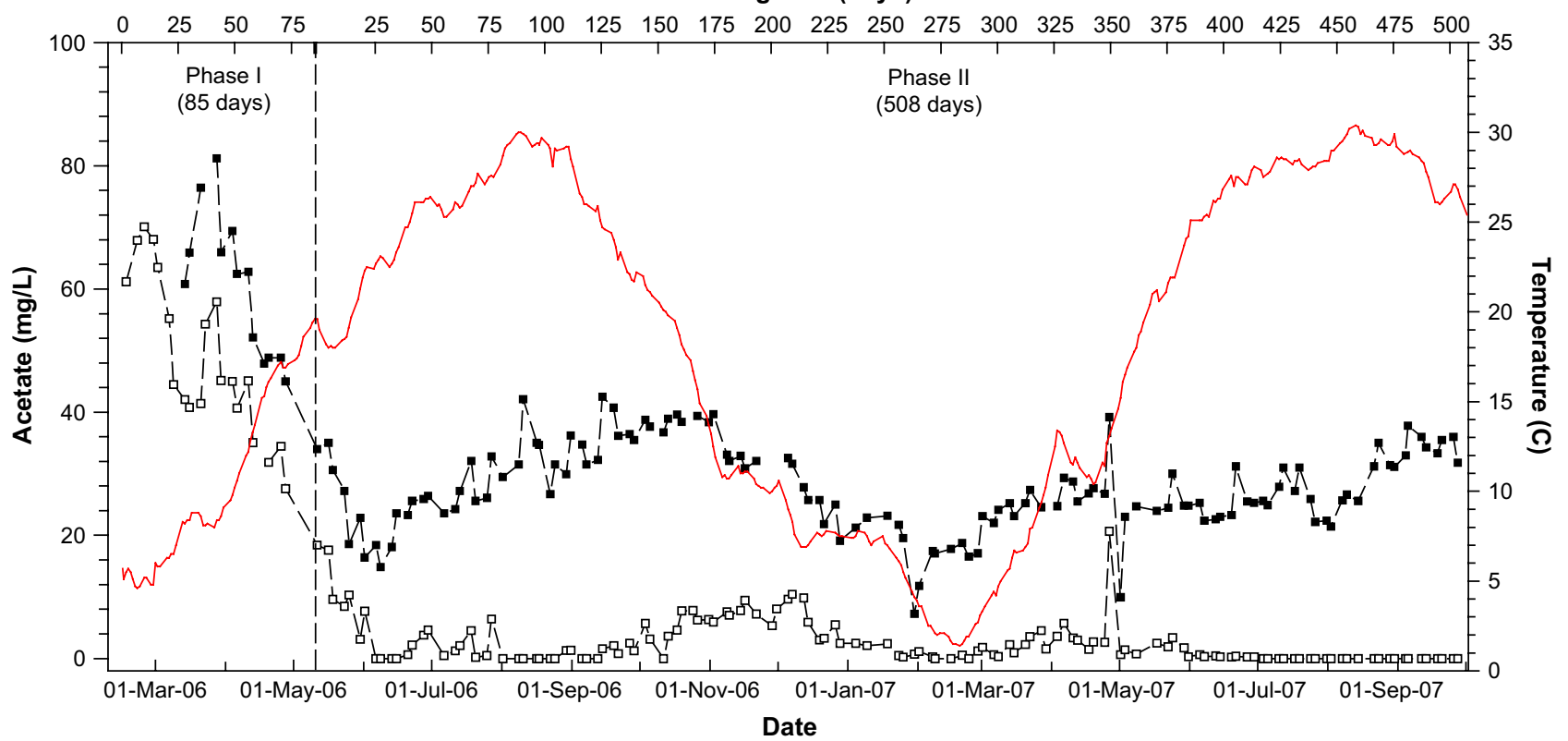

Fig. 6 - Acetate and temperature: $-\rightarrow-$ Contactor influent concentration (left axis), ---- Contactor effluent concentration (left axis), — Temperature (right axis), Acetate MDL $=0.001 \mathrm{mg} / \mathrm{L}$.

peak occurred on days 28 and 33, measuring 91 and $77 \mu \mathrm{g} / \mathrm{L}$, respectively. This peak coincided with the perchlorate and nitrate excursions observed in the same time interval. A period of unstable effluent nitrite, with concentrations ranging from the MDL to $30 \mu \mathrm{g} / \mathrm{L}$, was observed between days 252 and 315. This time interval coincided with the coldest part of the winter and the observed deterioration in perchlorate and nitrate reduction.
Testing for sulfide (Fig. 8) in the contactor effluent was initiated on day 110 of Phase II, after a sulfide odor had become apparent. Effluent sulfide concentrations peaked at $6.4 \mathrm{mg} / \mathrm{L}$ on day 147. By this time, the temperature had fallen to $25^{\circ} \mathrm{C}$ from the summertime peak of $30^{\circ} \mathrm{C}$. From its peak, effluent sulfide dropped as the temperature dropped, plateauing below $0.1 \mathrm{mg} / \mathrm{L}$ between days 257 and 309. This time interval, beginning and ending at 6.1 and $6.7^{\circ} \mathrm{C}$, respectively, enclosed the

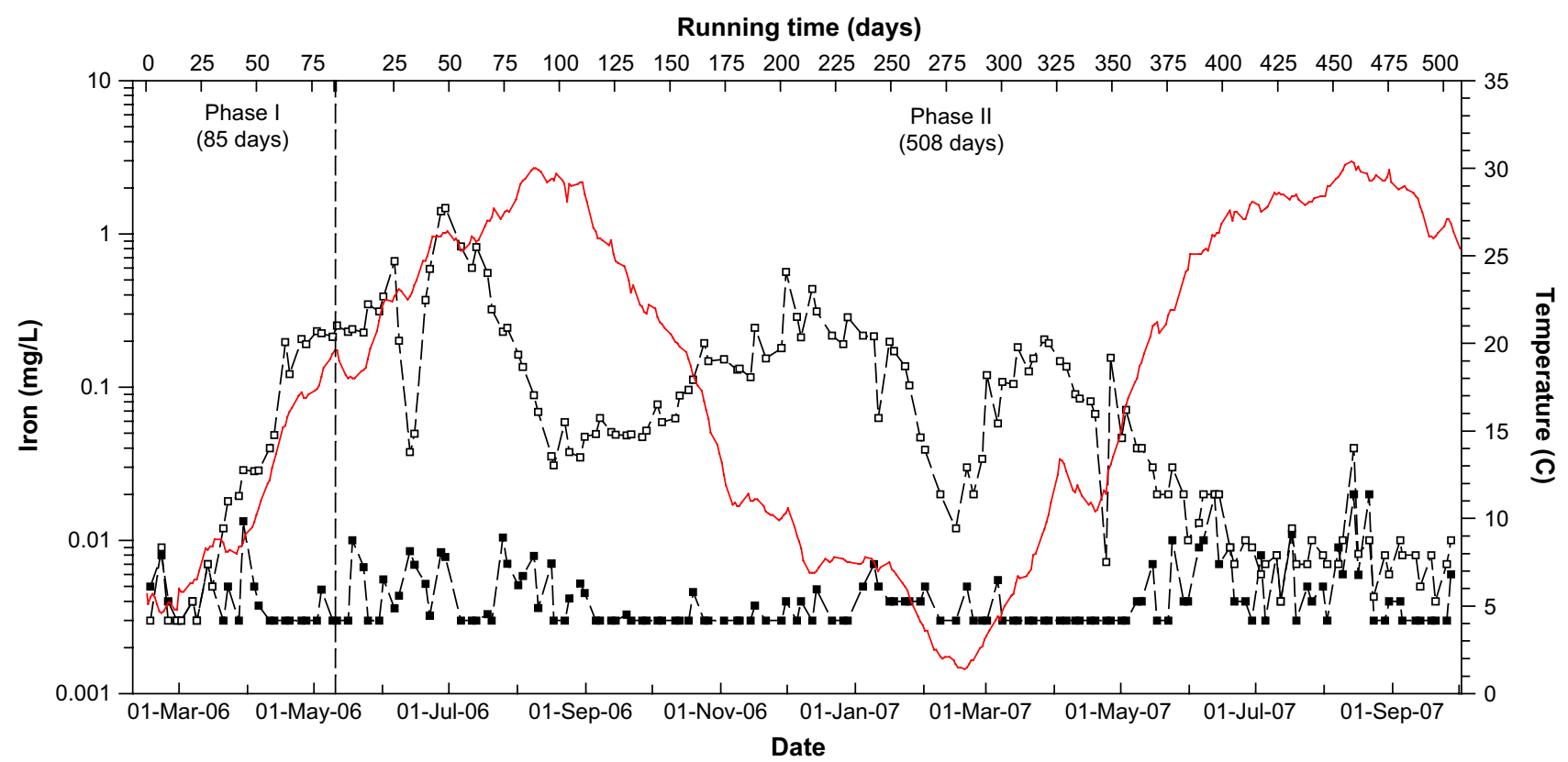

Fig. 7 - Iron and temperature: - - Contactor influent concentration (left axis), --- - Contactor effluent concentration (left axis), Temperature (right axis), Iron $\mathrm{MDL}=0.003 \mathrm{mg} / \mathrm{L}$. 


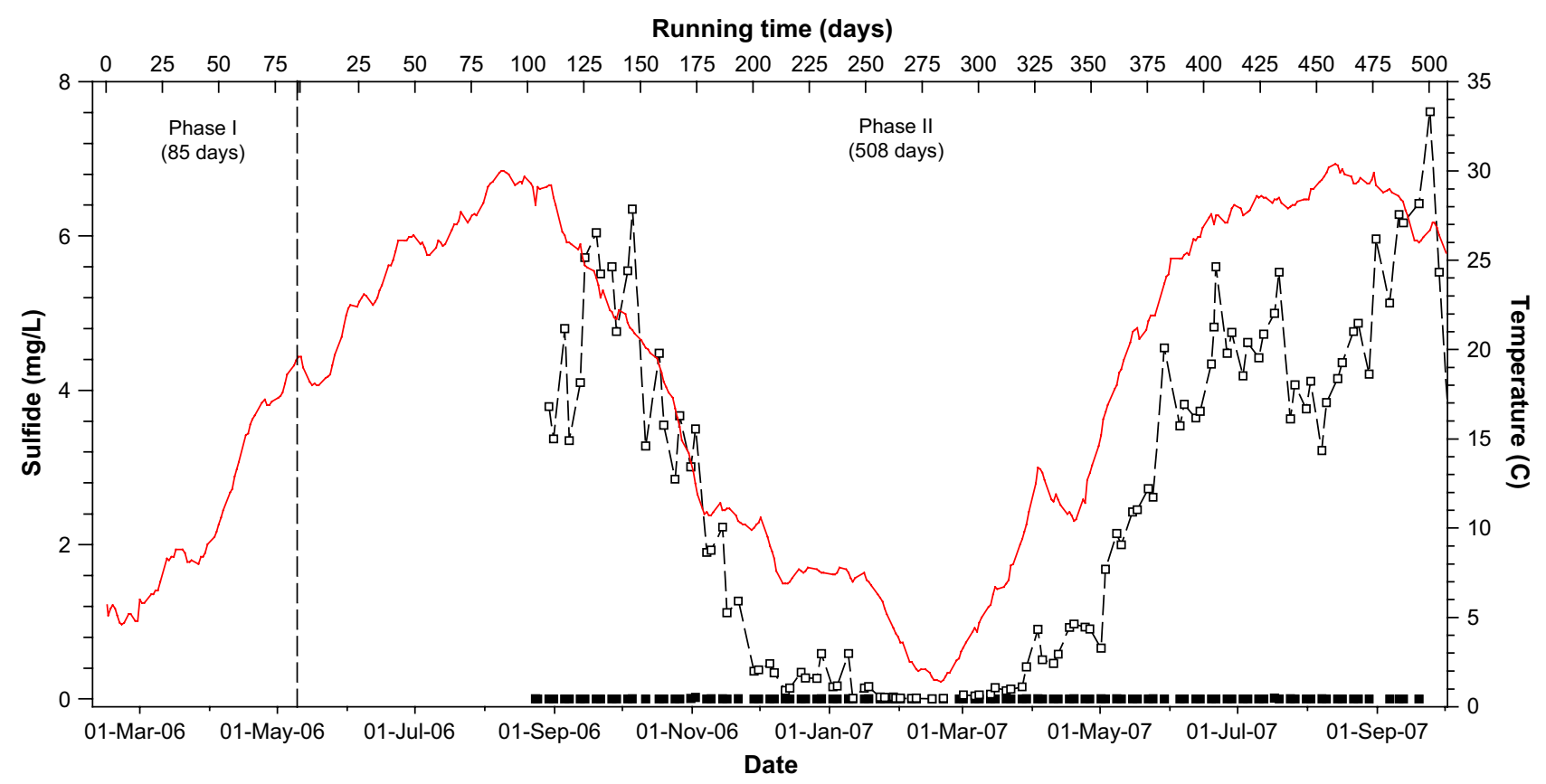

Fig. 8 - Sulfide and temperature: $-\rightarrow-$ Contactor influent concentration (left axis), ---- Contactor effluent concentration (left axis), Temperature (right axis), Sulfide MDL $=0.01 \mathrm{mg} / \mathrm{L}$.

lowest winter time temperature of $1.4^{\circ} \mathrm{C}$. As temperatures warmed, effluent sulfides increased, reaching a peak of $7.6 \mathrm{mg} /$ $\mathrm{L}$ on day 501. At this time, the temperature had fallen to $27^{\circ} \mathrm{C}$ from its summertime peak of $30^{\circ} \mathrm{C}$. Influent sulfate concentrations during Phase II averaged $79 \mathrm{mg} / \mathrm{L}\left(\sigma_{\mathrm{n}-1}=20 \mathrm{mg} / \mathrm{L}\right)$. Sulfide was never detected in the contactor influent. The sulfide method used in this study did not test specifically for hydrogen sulfide $\left(\mathrm{H}_{2} \mathrm{~S}\right)$. However, pilot plant personnel were equipped with hydrogen sulfide monitors while sampling and maintaining the unit. Ambient hydrogen sulfide concentrations never exceeded the $20 \mathrm{ppm}$ permissible exposure level set by the U.S. Occupational Safety and Health Administration (Occupational Safety and Health Standards, 2009).

Effluent ammonia (Fig. 9) concentrations in Phase II significantly exceeded influent concentrations during two separate time intervals. From days 21 to 110, effluent and influent ammonia concentrations averaged $0.11 \mathrm{mg} / \mathrm{L}\left(\sigma_{\mathrm{n}-1}=0.061 \mathrm{mg} /\right.$ L) and $<0.039 \mathrm{mg} / \mathrm{L}\left(\sigma_{\mathrm{n}-1}=0.025 \mathrm{mg} / \mathrm{L}\right)$, respectively. From days 357 to 469 , effluent and influent ammonia concentrations averaged $\quad 0.16 \mathrm{mg} / \mathrm{L} \quad\left(\sigma_{\mathrm{n}-1}=0.042 \mathrm{mg} / \mathrm{L}\right) \quad$ and $<0.037 \mathrm{mg} / \mathrm{L}$ $\left(\sigma_{\mathrm{n}-1}=0.016 \mathrm{mg} / \mathrm{L}\right)$, respectively. Both effluent ammonia excursions began in late spring and ended in the late summer. The MDL for ammonia during the study was $0.03 \mathrm{mg} / \mathrm{L}$.

Effluent dissolved oxygen (Fig. 3) levels during Phase II displayed the same time course as effluent perchlorate, nitrate, and sulfide. In the first two weeks of Phase II, effluent dissolved oxygen averaged $0.11 \mathrm{mg} / \mathrm{L} \quad\left(\sigma_{\mathrm{n}-1}=0.045 \mathrm{mg} / \mathrm{L}\right)$. These concentrations decreased throughout the spring, summer, and early autumn, averaging $0.037 \mathrm{mg} / \mathrm{L}$ $\left(\sigma_{\mathrm{n}-1}=0.022 \mathrm{mg} / \mathrm{L}\right)$ on days 189 through 202 . The temperature on day 202 was $10^{\circ} \mathrm{C}$. From this point, the effluent dissolved oxygen rose rapidly, to $2.5 \mathrm{mg} / \mathrm{L}$ by day 215 . This increase in effluent dissolved oxygen occurred approximately two weeks after the observed cold weather increase in effluent perchlorate and nitrate levels. From day 215, the effluent dissolved oxygen rose to a peak of $5.4 \mathrm{mg} / \mathrm{L}$ by day 286 , when the temperature was $1.7^{\circ} \mathrm{C}$. The timing of the effluent dissolved oxygen peak coincides exactly with the timing of the effluent nitrate and perchlorate peaks. The influent dissolved oxygen concentration on day 286 was $12.4 \mathrm{mg} / \mathrm{L}$. The resulting dissolved oxygen utilization of $7 \mathrm{mg} / \mathrm{L}$ implied the existence of significant microbial activity in the contactor, even during very cold weather. As temperatures increased, effluent dissolved oxygen declined steadily; dropping below $1 \mathrm{mg} / \mathrm{L}$ by day 302 when the temperature had reached $5^{\circ} \mathrm{C}$. From this day through day 361 , effluent dissolved oxygen was unstable, swinging between 0.90 and $0.036 \mathrm{mg} / \mathrm{L}$, with a mean of $0.30 \mathrm{mg} / \mathrm{L}\left(\sigma_{\mathrm{n}-1}=0.29 \mathrm{mg} / \mathrm{L}\right)$. This period of unstable effluent dissolved oxygen, between days 302 and 361, overlapped approximately with the period of unstable post-winter effluent perchlorate (days 322 through 385) and nitrate (days 322 through 383) concentrations. From days 361 through the end of Phase II, effluent dissolved oxygen remained low and stable, averaging $0.032 \mathrm{mg} / \mathrm{L}\left(\sigma_{\mathrm{n}-1}=0.019 \mathrm{mg} / \mathrm{L}\right)$.

During Phase II, the median effluent perchlorate (Fig. 2) concentration in the $20^{\circ} \mathrm{C}<\mathrm{T} \leq 30^{\circ} \mathrm{C}$ and $10^{\circ} \mathrm{C}<\mathrm{T} \leq 20^{\circ} \mathrm{C}$ temperature ranges was less than the $2 \mu \mathrm{g} / \mathrm{L}$ MDL (Table 1 ). However, the median effluent perchlorate concentration rose to $32 \mu \mathrm{g} / \mathrm{L}$ when the temperature dropped below $10^{\circ} \mathrm{C}$. Similar behavior was observed for nitrate, sulfate, and dissolved oxygen. Median effluent nitrate levels were below the $20 \mu \mathrm{g} / \mathrm{L} \quad \mathrm{MDL}$ when $20^{\circ} \mathrm{C}<\mathrm{T} \leq 30^{\circ} \mathrm{C}, \quad 22 \mu \mathrm{g} / \mathrm{L}$ when $10^{\circ} \mathrm{C}<\mathrm{T} \leq 20^{\circ} \mathrm{C}$, and $420 \mu \mathrm{g} / \mathrm{L}$ when $\mathrm{T} \leq 10^{\circ} \mathrm{C}$. Median effluent dissolved oxygen (Fig. 3) concentrations in the three temperature ranges were, from highest to lowest temperature: $0.033,0.060$ and $1.2 \mathrm{mg} / \mathrm{L}$, respectively. Sulfide (Fig. 8), on 


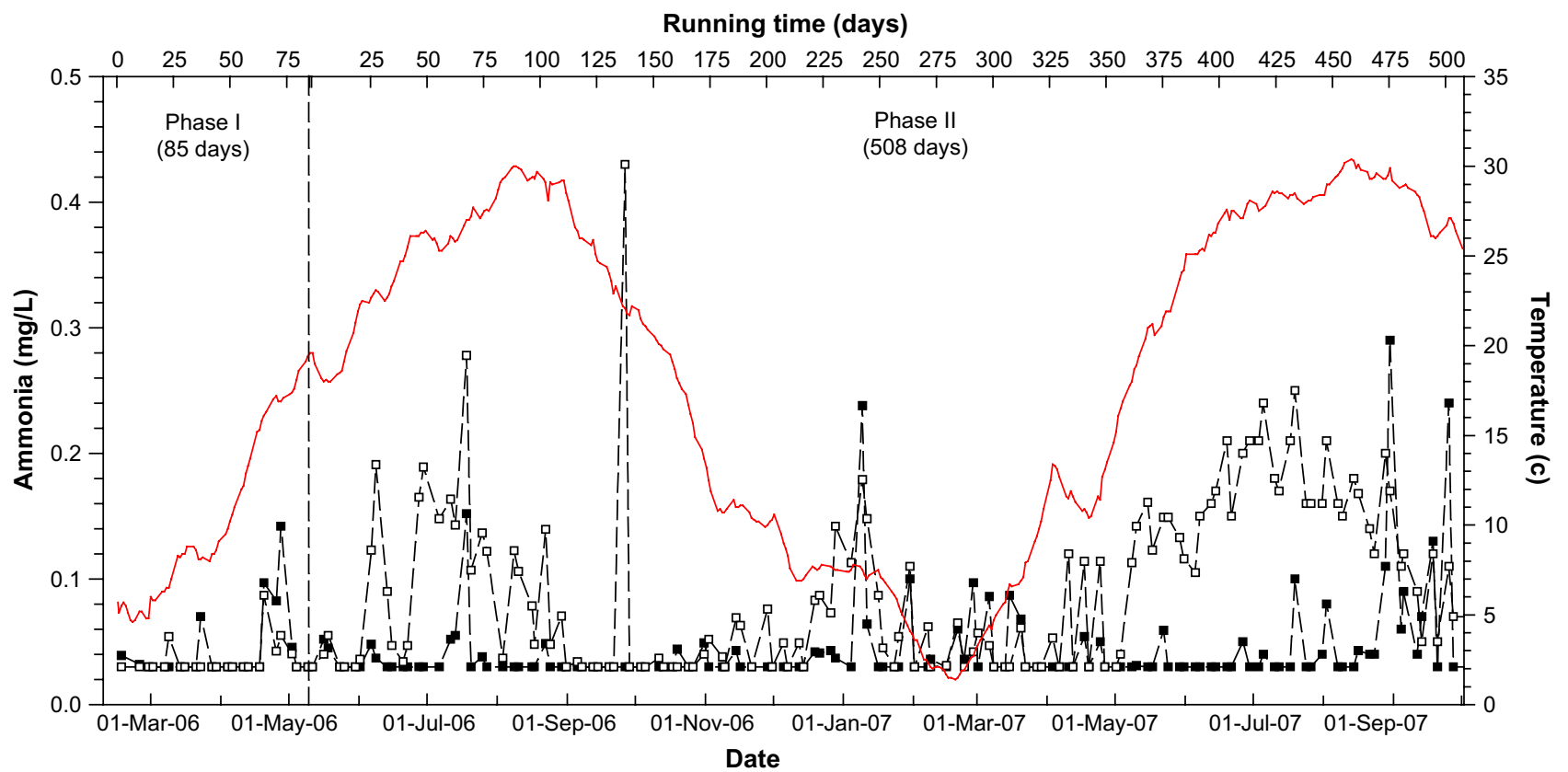

Fig. 9 - Ammonia and temperature: $-\rightarrow-$ Contactor influent concentration (left axis), ---- Contactor effluent concentration (left axis); Temperature (right axis), Ammonia MDL $=0.03 \mathrm{mg} / \mathrm{L}$.

the other hand, varied directly with temperature. Median effluent sulfide concentrations in the three temperature ranges were, from highest to lowest temperature: $4.5,1.3$ and $0.13 \mathrm{mg} / \mathrm{L}$, respectively.
Effluent iron (Fig. 7) concentrations peaked at $1.5 \mathrm{mg} / \mathrm{L}$ on day 49 of Phase II, rising from a relative low of $0.038 \mathrm{mg} / \mathrm{L}$ on day 33. The timing of the low iron concentration coincides exactly with the timing of the effluent perchlorate and nitrate

\section{Table 1 - Distribution of influent and effluent perchlorate, dissolved oxygen, nitrate and sulfide as a function of}

\section{temperature during Phase II.}

\begin{tabular}{|c|c|c|c|c|c|c|c|c|}
\hline \multirow[t]{2}{*}{ Analyte } & \multirow[t]{2}{*}{ Temperature $\left({ }^{\circ} \mathrm{C}\right)$} & \multirow[t]{2}{*}{ Sample point } & \multicolumn{6}{|c|}{ Percentile } \\
\hline & & & 10th & 25th & 50 th & 75 th & 90th & $n$ \\
\hline \multirow[t]{6}{*}{ Perchlorate $(\mu \mathrm{g} / \mathrm{L})$} & $\mathrm{T} \leq 10$ & Influent & 43 & 47 & 49 & 54 & 57 & 30 \\
\hline & & Effluent & 12 & 18 & 32 & 37 & 44 & 30 \\
\hline & $10<\mathrm{T} \leq 20$ & Influent & 42 & 45 & 48 & 51 & 53 & 34 \\
\hline & & Effluent & $<2$ & $<2$ & $<2$ & 2.8 & 8.9 & 34 \\
\hline & $20<\mathrm{T} \leq 30$ & Influent & 43 & 45 & 50 & 54 & 60 & 34 \\
\hline & & Effluent & $<2$ & $<2$ & $<2$ & $<2$ & 4.1 & 34 \\
\hline \multirow[t]{6}{*}{ Dissolved Oxygen (mg/L) } & $\mathrm{T} \leq 10$ & Influent & 11 & 12 & 13 & 13 & 13 & 43 \\
\hline & & Effluent & 0.18 & 0.65 & 1.2 & 2.6 & 4.5 & 75 \\
\hline & $10<\mathrm{T} \leq 20$ & Influent & 8.1 & 8.4 & 10 & 11 & 12 & 51 \\
\hline & & Effluent & 0.019 & 0.024 & 0.060 & 0.087 & 0.20 & 76 \\
\hline & $20<\mathrm{T} \leq 30$ & Influent & 5.9 & 6.3 & 6.9 & 7.5 & 8.3 & 125 \\
\hline & & Effluent & 0.016 & 0.023 & 0.033 & 0.051 & 0.079 & 186 \\
\hline \multirow[t]{6}{*}{ Nitrate $(\mathrm{mg} / \mathrm{L})$} & $\mathrm{T} \leq 10$ & Influent & 0.81 & 0.89 & 0.95 & 1.0 & 1.2 & 31 \\
\hline & & Effluent & 0.11 & 0.20 & 0.42 & 0.60 & 0.76 & 30 \\
\hline & $10<\mathrm{T} \leq 20$ & Influent & 0.55 & 0.66 & 0.77 & 0.86 & 0.96 & 30 \\
\hline & & Effluent & $<0.02$ & $<0.02$ & 0.022 & 0.052 & 0.13 & 30 \\
\hline & $20<\mathrm{T} \leq 30$ & Influent & 0.53 & 0.62 & 0.78 & 0.92 & 1.3 & 78 \\
\hline & & Effluent & $<0.02$ & $<0.02$ & $<0.02$ & 0.040 & 0.050 & 78 \\
\hline \multirow[t]{6}{*}{ Sulfide (mg/L) } & $\mathrm{T} \leq 10$ & Influent & $<0.001$ & $<0.001$ & $<0.001$ & 0.003 & 0.004 & 33 \\
\hline & & Effluent & 0.011 & 0.026 & 0.13 & 0.27 & 0.36 & 32 \\
\hline & $10<\mathrm{T} \leq 20$ & Influent & $<0.001$ & $<0.001$ & 0.002 & 0.004 & 0.007 & 25 \\
\hline & & Effluent & 0.51 & 0.90 & 1.3 & 2.2 & 3.6 & 25 \\
\hline & $20<\mathrm{T} \leq 30$ & Influent & $<0.001$ & $<0.001$ & 0.002 & 0.003 & 0.004 & 49 \\
\hline & & Effluent & 3.3 & 3.8 & 4.5 & 5.5 & 6.0 & 51 \\
\hline
\end{tabular}

NOTE: A " < " before a table entry indicates that the value is reported at the detection limit. 
peaks. From its peak on day 49, effluent iron trended gradually downward for the remainder of Phase II, averaging $3.8 \mu \mathrm{g} / \mathrm{L}$ $\left(\sigma_{\mathrm{n}-1}=6.5 \mu \mathrm{g} / \mathrm{L}\right)$ during the last three months of the phase. By comparison, the influent iron concentration throughout Phase II averaged $<6.2 \mu \mathrm{g} / \mathrm{L}\left(\sigma_{\mathrm{n}-1}=1.8 \mu \mathrm{g} / \mathrm{L}\right)$.

Raw $\mathrm{pH}$, prior to acetic acid addition, averaged 7.5 $\left(\sigma_{\mathrm{n}-1}=0.15\right)$ during Phase II. Influent and effluent $\mathrm{pH}$ values during Phase II averaged $6.4\left(\sigma_{\mathrm{n}-1}=0.20\right)$ and $6.8\left(\sigma_{\mathrm{n}-1}=0.16\right)$, respectively. The $\mathrm{pH}$ depression from raw to influent was less pronounced than during Phase I because acetic acid doses were lower.

\section{Discussion}

Despite low temperatures, significant biological activity was observed within the first two weeks of contactor operation. The time progression of biological activity, with respect to the initiation of perchlorate reduction, agrees with previously published investigations of microbial perchlorate metabolism and reduction potentials in aqueous systems. The reduction of nitrate to molecular nitrogen $\left(\mathrm{N}_{2}\right)$ has a reduction potential $\left(E_{\mathrm{o}}\right)$ of $1.25 \mathrm{~V}$ (Pankow, 1991). The $E_{\mathrm{o}}$ for the reduction of perchlorate to chloride is $1.29 \mathrm{~V}$ (Coates and Achenbach, 2004). Because of their similar reduction potentials, nitrate can compete with perchlorate as an electron acceptor (Coates and Achenbach, 2004). In the current study, the initiation of nitrate reduction and a transient period of nitrite formation preceded the initiation of perchlorate reduction. In contrast, Brown et al. (2005) observed concurrent establishment of nitrate and perchlorate reduction during their acclimation phase. The difference in results observed by Brown et al. (2005) may have been due to their use of adsorptive (activated carbon) instead of inert media, repositioning of their acetate injection point during acclimation, higher temperatures, or a different microbial consortium.

Competition with nitrate may also explain the transient episode observed between days 28 and 39 of Phase II, when perchlorate reduction ceased completely. The influent nitrate during this period rose to a peak more then four standard deviations greater than the mean for the entire study. The stable and almost complete consumption of acetate and dissolved oxygen during this period indicate a high level of microbial activity. Under these conditions, it is possible that preferential reduction of the high transient nitrate left insufficient electron donor available to support perchlorate reduction. In fact, the effluent data imply the possibility of insufficient electron donor to fully reduce even the influent nitrate. Nitrate was still present in the effluent, at a concentration 70 percent lower than the influent. Nitrite was also present in the effluent, implying that not all of the reduced nitrate was completely converted to nitrogen. Brown et al. (2005) observed similar results when the influent nitrate was increased by a factor of 4.8 without a corresponding increase in influent acetate. Influent nitrate was still reduced by more than 90 percent. However, perchlorate removal deteriorated from 100 percent to 20-60 percent, and nitrite appeared in the effluent. The negative impact of transient nitrate spikes on perchlorate reduction implies that any microbial perchlorate treatment process would need to incorporate a back-up treatment, such as ion exchange. The probability of perchlorate excursions would be further reduced through the adjustment of influent electron donor concentrations in response to real-time monitoring of influent dissolved oxygen, nitrate, and perchlorate levels. This would ensure that influent electron donor concentrations, in this case acetate, are sufficient to satisfy electron donor:acceptor molar ratios of 4:1, 5:1, and 8:1 for dissolved oxygen, nitrate, and perchlorate, respectively. Acetate above and beyond these molar requirements would need to be added to ensure sufficient concentrations for the maintenance and synthesis of microbial cells within the anaerobic contactor.

Microbial sulfate reduction, and the resulting production of sulfide, was a significant nuisance factor. Of the pilot-scale studies discussed in the Introduction, only Brown et al. (2005) reported testing for sulfide. Brown and coworkers did not detect sulfide above their method reporting limit of $0.1 \mathrm{mg} / \mathrm{L}$ and reported only occasional detections by smell. Influent sulfate concentrations and acetate doses in Brown's study ranged from 140 to $250 \mathrm{mg} / \mathrm{L}$ as sulfate, and 17 to $30 \mathrm{mg} / \mathrm{L}$ as acetate, respectively. During Phase II of the current study, contactor influent sulfate concentrations averaged $79 \mathrm{mg} / \mathrm{L}$ $\left(\sigma_{\mathrm{n}-1}=22 \mathrm{mg} / \mathrm{L}\right)$, and acetate concentrations ranged from 18 to $27 \mathrm{mg} / \mathrm{L}$. Higher sulfide production during the current study may have been due to a longer empty bed contact time of $1.2 \mathrm{~h}$, versus $0.17-0.5 \mathrm{~h}$ reported by Brown et al. Higher temperatures during the current study may also account for some of the observed differences in effluent sulfide concentrations. While reducing the contact time may suppress sulfide production, it may also impair the ability of a biological contactor to eliminate perchlorate at lower temperatures. The conversion of sulfate to hydrogen sulfide has an $E_{0}$ of $0.30 \mathrm{~V}$ (Pankow, 1991), so perchlorate is preferentially reduced. Thus, reducing the influent acetate concentration, while still maintaining complete perchlorate reduction, might be an effective method of suppressing sulfide formation. However, such tight control of influent electron donor concentrations requires the ability, not available during this study, to analyze perchlorate in real time in order to ensure that the primary objective of perchlorate reduction is not compromised. Even if a drinking water utility has real-time perchlorate analysis capabilities, conservative design principles and safety considerations would dictate the downstream installation of an off-gas control process.

The formation of ammonia observed in the contactor could be attributed to the activity of sulfate reducing bacteria (Muyzer and Stams, 2008; López-Cortés et al., 2006; Moura et al., 1997; Dalsgaard and Bak, 1994; Keith and Herbert, 1983) or ammonifiers (Ferguson and Richardson, 2004). The presence of ammonia in the effluent has the potential for negative impacts on downstream treatment processes. These include higher chlorine demand and an elevated potential for distribution system nitrification. It is possible that ammonia production could also be suppressed through tighter control of influent electron donor concentrations.

Support gravel was the most likely source of the iron observed in the contactor effluent. The long-term downward trend in the effluent iron concentration over the course of the study implies a finite reservoir, such as that contained in a gravel bed. Iron (III) in the gravel would have been reduced to 
soluble iron (II), either chemically or microbially. A relative minimum in effluent iron concentrations on day 33 of Phase II coincides exactly with the previously discussed influent nitrate spike and attendant deterioration in perchlorate reduction. The reduction of iron (III) to iron (II) has an $E_{\mathrm{o}}$ of $0.77 \mathrm{~V}$ (Pankow, 1991), lower than that of perchlorate or nitrate. Thus, iron reduction could have been upset by the temporarily high concentrations of a competing electron acceptor. The effluent iron and its probable source indicate that support media and underdrains for a full-scale downflow anaerobic system would need to be chosen with care. The underdrain/support structure would either require gravel with a low iron content or be of the type that does not require gravel.

The impact of cold temperatures on effluent perchlorate, nitrate, dissolved oxygen, and sulfide was significant (Table 1). As temperatures dropped from the highest to the middle temperature range, median perchlorate remained below its MDL, median dissolved oxygen doubled, median nitrate increased from below to barely above its MDL, and sulfide decreased by 71 percent. However, at temperatures below $10^{\circ} \mathrm{C}$, median effluent perchlorate, dissolved oxygen, and nitrate concentrations increased by $>1.2,1.3$, and 1.3 orders of magnitude, respectively, compared to the middle $\left(10^{\circ} \mathrm{C}<\mathrm{T}<20^{\circ} \mathrm{C}\right)$ temperature range. Effluent sulfide concentrations dropped by 1 order of magnitude under the same circumstances. These results indicate that $10{ }^{\circ} \mathrm{C}$ may be a critical threshold temperature for effective microbial perchlorate reduction under the conditions prevailing in this study. The process is fairly robust above $10^{\circ} \mathrm{C}$, but severely limited below that temperature. These results indicate the need for a non-biological backup process in situations with wide seasonal temperature variations.

\section{Conclusions}

An anaerobic biological perchlorate treatment reactor was successfully acclimated using indigenous microorganisms. The contactor was operated continuously for 20 months over a wide seasonal temperature range. The data collected during the study confirm the feasibility of biologically treating perchlorate to consistently low $(<2 \mu \mathrm{g} / \mathrm{L})$ levels at temperatures above $10^{\circ} \mathrm{C}$. However, the results also demonstrate that tight operational control and process redundancy are required for reliable long-term operation in a surface water application, where temperatures and influent quality can vary widely. Successful operation would require at least daily real-time analyses of acetate, sulfide, perchlorate, and competing electron acceptor concentrations. Operators would require training to interpret the results and adjust feed chemical concentrations accordingly. The biological process would require a secondary downstream removal process, such as ion exchange. This downstream process would be needed to remove residual perchlorate from the bioreactor effluent during the winter and during upsets. Finally, the biological system produces an effluent that is potentially low in dissolved oxygen and high in sulfide, ammonia, soluble microbial products, and acetate. All of these have the potential to negatively impact distribution system water quality by contributing to unpleasant odors, increased microbial activity, higher chlorine demand, and higher disinfection by-product formation. Further research is currently underway to investigate the downstream control of particles, sulfide, organic compounds, and disinfection by-product formation potential by aeration, biologically active aerobic granular media filtration, and ultrafiltration.

\section{Acknowledgments}

The authors would like to thank Keith Kelty, Brittany Almassalkhi, Stephanie Brown, Jeffery Collins, David Griffith, Andrew Hughett, Nathan Musin, and Eugenia Riddick of the U.S. Environmental Protection Agency for performing the laboratory analyses. The authors are also grateful to Leonard Engel, Michael Girten, Katherine Jamriska, and Norman Payne, all shift chemists with the Greater Cincinnati Water Works' Water Quality Division, for helping to monitor the pilot system; and finally to Paul Anderson, Verna Arnette, John Koch, Larry Kuhl, Jim Queen, Randy Schmidt and Greg Simmons, all with the Greater Cincinnati Water Works' Water Supply Division, for their logistical assistance.

Notice: The U.S. Environmental Protection Agency, through its Office of Research and Development, funded and managed, or partially funded and collaborated in, the research described herein. It has been subjected to the Agency's administrative review and has been approved for external publication. Any opinions expressed in this paper are those of the author (s) and do not necessarily reflect the views of the Agency; therefore, no official endorsement should be inferred. Any mention of trade names or commercial products does not constitute endorsement or recommendation for use.

\section{R E F E R E N C E S}

Brown, J.C., Anderson, R.D., Min, J.H., Boulos, L., Prasifka, D., Juby, G.J.G., 2005. Fixed-bed biological treatment of perchlorate-contaminated drinking water. Journal AWWA 97 (9), 70-81.

Coates, J.D., Achenbach, L.A., 2004. Microbial perchlorate reduction: rocket-fuelled metabolism. Nature Reviews: Microbiology 2, 569-580.

Dalsgaard, T., Bak, F., 1994. Nitrate reduction in a sulfate-reducing bacterium, Desulfovibrio desulfuricans, isolated from rice paddy soil: sulfide inhibition, kinetics and regulation. Applied and Environmental Microbiology 60 (1), 291-297.

Dasgupta, P.K., Martinelangelo, P.K., Jackson, W.A., Anderson, T.A., Tian, K., Tock, R.W., Rajagopalan, S., 2005. The origin of naturally occurring perchlorate: the role of atmospheric processes. Environmental Science and Technology 39, 1569-1575.

Eaton, A.D., Clesceri, L.S., Rice, E.W., Greenberg, A.E., Franson, M.H. (Eds.), 2005. Standard Methods for the Examination of Water and Wastewater, twenty-first ed. American Public Health Association, American Water Works Association, Water Environment Federation, Washington, D.C.

Ferguson, S.J., Richardson, D.J., 2004. The enzymes and bioenergetics of bacterial nitrate, nitrite, nitric oxide and nitrous oxide respiration. In: Zannoni, D. (Ed.), Respiration in Archaea and Bacteria: Diversity of Prokaryotic Respiratory 
Systems. Advances in Photosynthesis and Respiration, vol. 16. Springer, New York, pp. 170-201.

Fuller, M.E., Hatzinger, P.B., Condee, C.W., Togna, A.P., 2007. Combined treatment of perchlorate and RDX in ground water using a fluidized bed reactor. Ground Water Monitoring and Remediation 27 (3), 59-64.

Greater Cincinnati Water Works, 2007. 2007 Safe Drinking Water Report. City of Cincinnati, Greater Cincinnati Water Works Web site. http://www.cincinnati-oh.gov/water/downloads/ water_pdf15886.pdf (accessed 03.04.08).

Hach Company, 2008. Hach Water Analysis Handbook Procedures, fifth ed. Hach Company. Web site. http://www. hach.com, Information Central, Download Resources (accessed 08.04.08).

Keith, S.M., Herbert, R.A., 1983. Dissimilatory nitrate reduction by a strain of Desulfovibrio desulfuricans. FEMS Microbiology Letters 18, 55-59.

Kosaka, K., Asami, M., Matsuoka, Y., Kamoshita, M., Kunikane, S., 2007. Occurrence of perchlorate in drinking water sources of metropolitan area in Japan. Water Research 41, 3474-3482.

López-Cortés, A., Fardeau, M., Fauque, G., Joulian, C., Ollivier, B., 2006. Reclassification of the sulfate- and nitrate-reducing bacterium Desulfovibrio vulgaris Subsp. oxamicus as Desulfovibrio Oxamicus Sp. Nov., Comb. Nov. International Journal of Systematic and Evolutionary Microbiology 56, 1495-1499.

Min, B., Evans, P.J., Chu, A.K., Logan, B.E., 2004. Perchlorate removal in sand and plastic media bioreactors. Water Research 38, 47-60.

Moura, I., Bursakov, S., Costa, C., Moura, J.J.G., 1997. Nitrate and nitrite utilization in sulfate-reducing bacteria. Anaerobe 3, 279-290.

Muyzer, G., Stams, A.J.M., 2008. The ecology and biotechnology of sulphate-reducing bacteria. Nature Reviews: Microbiology 6, 441-454.

Occupational Safety and Health Standards, 2009. 29 Code of Federal Regulations, Part 1910, Subpart Z, 1910.1000, Table Z-2.

Pankow, J.F., 1991. Aquatic Chemistry Concepts. Lewis Publishers, Chelsea, Michigan, pp. 493-545.

Quinones, O., Oh, J., Vanderford, B., Kim, J.H., Cho, J., Snyder, S.A., 2007. Perchlorate assessment of the Nakdong and Yeongsan watersheds, Republic of Korea. Environmental Toxicology and Chemistry 26 (7), 1349-1354.
Rajagopalan, S., Anderson, T.A., Fahlquist, L., Rainwater, K.A., Ridley, M., Jackson, W.A., 2006. Widespread presence of naturally occurring perchlorate in high plains of Texas and New Mexico. Environmental Science and Technology 40, 3156-3162.

Rao, B., Anderson, T.A., Orris, G.J., Rainwater, K.A., Rajagopalan, S., Sandvig, R.M., Scanlon, B.R., Stonestrom, D.A., Walvoord, M.A., Jackson, W.A., 2007. Widespread natural perchlorate in unsaturated zones of the Southwest United States. Environmental Science and Technology 41, 4522-4528.

Schumacher, J.C., 1960. Perchlorates: Their Properties, Manufacture and Uses. In: American Chemical Society Monograph Series, vol. 146. Reinhold Publishing Corporation, New York.

Trumpolt, C.W., Crain, M., Cullison, G.D., Flanagan, S.J.P., Siegel, L., Lathrop, S., 2005. Perchlorate: sources, uses and occurrences in the environment. Remediation Journal 16 (1), 65-89.

U.S. Environmental Protection Agency, 1993. Methods for Chemical Analysis of Water and Wastes. EPA/600/R-93/100, Washington, D.C.

U.S. Environmental Protection Agency, 1994. Methods for the Determination of Metals in Environmental Samples (Supplement 1). EPA/600/R-94/111, Washington, D.C.

U.S. Environmental Protection Agency, 1999. Revisions to the unregulated contaminant monitoring regulation for public water systems; final rule. Federal Register 64 (180), 50555-50620.

U.S. Environmental Protection Agency, 2000. Methods for the Determination of Organic and Inorganic Compounds in Drinking Water. EPA/815/R-00/014, Washington, D.C.

U.S. Environmental Protection Agency, 2006. UCMR List 1 and List 2 Chemical Monitoring Data (Updated January 2006). Unregulated Contaminant Monitoring Program Web site. http://www.epa.gov/safewater/ucmr/data/ucmr1_ list1and2chem.zip (accessed 20.03.08).

U.S. Environmental Protection Agency, 2007. Unregulated contaminant monitoring regulation (UCMR) for public water systems revisions; final rule. Federal Register 72 (2), 367-398.

Xu, J., Song, Y., Min, B., Steinberg, L., Logan, B.E., 2003. Microbial degradation of perchlorate: principles and applications. Environmental Engineering Science 20 (5), 405-422. 